doi: 10.19090/i.2019.30.187-196

UDC: 316.4(497.1):929 Jeftanović G.

BOŠKO M. BRANKOVIĆ

University of Banja Luka, Faculty of Philosophy

Department of History

bosko.brankovic@ff.unibl.org

\title{
CORRESPONDENCE BETWEEN GLIGORIJE JEFTANOVIĆ AND THE GREAT ADMINISTRATIVE AND EDUCATIONAL COUNCIL IN 1919
}

\begin{abstract}
The paper follows the correspondence between Gligorije Jeftanović and the Great Administrative and Educational Council in the year 1919. The first part of the text presents the correspondence where the Great Administrative and Educational Council requests an opinion from Jeftanović about the secession of the Serbian Orthodox Church in Bosnia and Herzegovina from the Constantinople Patriarchate and merging with the Serbian Patriarchate. The second part of the text presents the correspondence that concerned Jeftanović's membership in the Great Administrative and Educational Council and his pre-war position as the Deputy Chairman of the Great Administrative and Educational Council, from which he was removed by the occupation Austro-Hungarian authorities during the First World War and, as he claimed in the correspondence, with the assistance of people from the Great Administrative and Educational Council.

Keywords: Gligorije Jeftanović, Serbian Orthodox Church, Kingdom of Serbs, Croats and Slovenes (Kingdom of SHS), Bosnia and Herzegovina, the Great Administrative and Educational Council.
\end{abstract}

$\mathrm{T}$ The end of the First World War brought the liberation and unification of all Serb provinces and thus created a possibility of unifying all six former regional churches into one independent Serbian Orthodox Church. ${ }^{1}$ Immediately after the unification and creation of the Kingdom of Serbs, Croats and Slovenes, in all Serbian regional churches where there was religious and ecclesiastical autonomy through which religious and national work was conducted and where there were strong religious-self-governing habits, the Serbian people began to demand the establishment of a self-governing ecclesiastical organization abolished during the war and to improve it and establish it within the united Serbian Orthodox Church. ${ }^{2}$ At that moment, Orthodox churches in Serbia and Montenegro had the status of a state religion, while Orthodox churches in other parts of the joint state

Luković 1929: 629; Ljubibratić 1928: 42; Slijepčević 2002: 556; Novaković 2014: 43.

Ljubibratić 1928: 43. 
had a different relation of the state towards them and of them towards the state. At the very beginning, a stronger influence of Serbia and Montenegro began to emerge, which was particularly seen through the press and through the Ministry of Religion, through which the state interfered with petty issues related to the church, which was contrary to earlier practice in the life of the Orthodox Church in Bosnia and Herzegovina. ${ }^{3}$

Preparations for the proclamation of the unification of all Serbian churches into one unit lasted from 31 December 1918, when a Conference of representatives of all Serbian churches was held in Sremski Karlovci until 26 May 1919, ${ }^{4}$ when the assembly of all Serbian Orthodox bishops decided to execute the unification:

\begin{abstract}
At the Conference of 31 December 1918, the Decision of the Bosnian-Herzegovinian bishops made on 14 December 1918 was read that they wanted to unite with the rest of our Church. And the Holy Synod of the Metropolitanate of Karlovci also brought the Decision on unification, which was read at this Conference. The Metropolitan of Montenegro, Mitrofan Ban, could not attend this conference due to illness, but at the beginning of 1919 he approved the church unification. The Holy Archbishopric Assembly of the Serbian Orthodox Church in the Kingdom of Serbia agreed on the unification on 13 March $1919 .{ }^{5}$
\end{abstract}

The second Conference of representatives of all Serbian churches was held from 24 to 28 May 1919, which confirmed the decision to unite and elect the Central Archbishopric Assembly of the United Serbian Church, which was tasked to represent the entire Serbian Orthodox Church, i.e. all Serbian provincial churches, and to be the Executive Body of all archival conferences in order to prepare the necessary material for the ultimate unification of the Serbian Orthodox Church. ${ }^{6}$

Negotiations with the Holy Synod of the Constantinople Patriarchate were completed after the resignation of the Constantinople Patriarch German V in 1920. The Holy Synod of the Constantinople Patriarchate gave its blessing for the Church's liberation from its ecclesiastical authority and the merge with the autocephalous united Serbian Orthodox Church to Serbian Metropolitanate under its administration on 18 March 1920. ${ }^{7}$

After preparing everything that was in line with the canonical regulations, the Royal Decree of the regent Aleksandar from 17 June 1920 announced the unification of all Serbian churches into one - the Serbian Orthodox Church, and on 12 September 1920 the Serbian Orthodox Church was proclaimed the Patriarchate. Dimitrije (Pavlović) was elected the first Serbian Patriarch. ${ }^{8}$

During the negotiations with the Constantinople Patriarchate in 1919 in Bosnia and

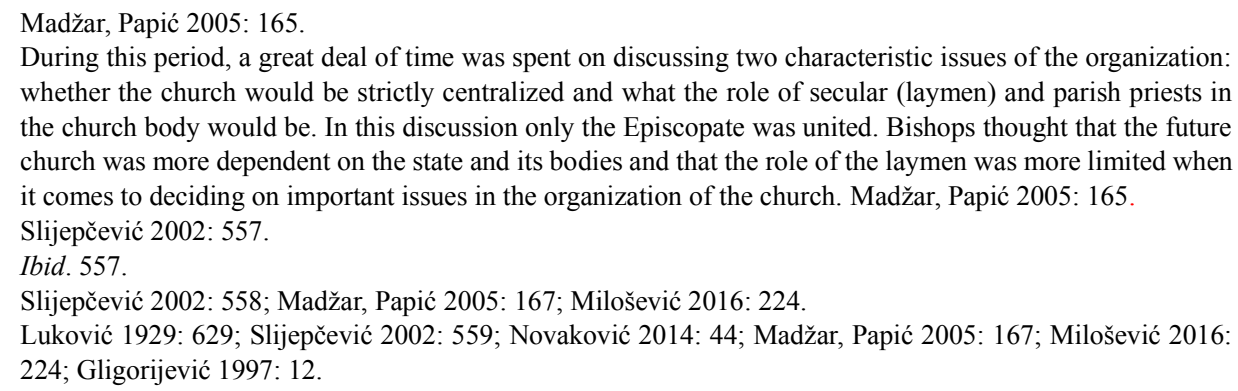

During this period, a great deal of time was spent on discussing two characteristic issues of the organization: whether the church would be strictly centralized and what the role of secular (laymen) and parish priests in the church body would be. In this discussion only the Episcopate was united. Bishops thought that the future church was more dependent on the state and its bodies and that the role of the laymen was more limited when it comes to deciding on important issues in the organization of the church. Madžar, Papić 2005: 165.

Slijepčević 2002: 557.

Ibid. 557.

Slijepčević 2002: 558; Madžar, Papić 2005: 167; Milošević 2016: 224.

Luković 1929: 629; Slijepčević 2002: 559; Novaković 2014: 44; Madžar, Papić 2005: 167; Milošević 2016: 224; Gligorijević 1997: 12. 
Herzegovina, ${ }^{9}$ which was ecclesiastically under the jurisdiction of this Patriarchate, the Great Administrative and Educational Council had an important role for the canonical secession from the Constantinople Patriarchate and the merge with the Serbian Patriarchate. ${ }^{10}$ And since in the Great Administrative and Educational Council, besides priests, secular persons were present as well, as it was necessary to obtain their opinion and consent for the secession from the Constantinople Patriarchate and the merging with the united Serbian Patriarchate. ${ }^{11}$

Gligorije Jeftanović ${ }^{12}$ was a member of the Great Administrative and Educational Council from 1905 to $1914 ;{ }^{13}$ therefore, it was necessary to obtain his opinion on granting the consent of the Great Administrative and Educational Council for the secession from the

9 According to the Censuses in Bosnia and Herzegovina, in 1910 there were 825,418, and in 1921 there were 826,162 Orthodox Serbs. Davidović 1991: 81; Popis žiteljstva 1910. godine; Popis stanovništva 1921. godine.

10 The Orthodox Church in Bosnia and Herzegovina had the adjective "Serbian" even in the worst times of the AustroHungarian occupation and it entered the new state union in an organization created after the struggle for churchschool autonomy in 1905. By adopting the Decree on the Organization of Self-Governing Church-Educational Opportunities in 1905, the Serbian Orthodox Church in the occupied provinces of Bosnia and Herzegovina consisted of four Metropolitanates: Dabar and Bosnia with the seat in Sarajevo, Zahumlje and Herzegovina with its seat in Mostar, Zvornik and Tuzla with the seat in Tuzla and Banja Luka and Bihac with the seat in Banja Luka. The Decree stipulated that the Great Administrative and Educational Council represented the supreme governance and educational authority for all Metropolitanates in Bosnia and Herzegovina. Members of the Great Administrative and Educational Council were: Metropolitan of Dabar and Bosnia, Metropolitan of Zvornik and Tuzla, Metropolitan of Zahumlje and Herzegovina, Metropolitan of Banja Luka and Bihać, one presbyter from each Metropolitan, four secular persons from each Metropolitanate and one teacher or professor from every Metropolitanate. Madžar, Papić 2005: 164; Milošević 2017: 81; Novaković 2003: 107; Istočnik 1905: 231.

11 Although the bishops were for the centralized organization of the church and the limitation of the role of secular persons and lower clergy in deciding on various issues within the future unified church, representatives of the lower clergy and secularists from Bosnia and Herzegovina insisted during the negotiations on the restriction of the authority of the bishop and on the foundation of the National Church Council, which would pass church laws and elect bishops. The reason for this stand was in the earlier behaviour of the bishops during the occupation administration in Bosnia and Herzegovina, which was evident from the controversy with the Metropolitan of Dabar and Bosnia Evgenije Letica in the newspaper the Serbian Church in 1919: "Our church bureaucracy was largely on the side of the enemy. Ever since the past two or three decades, the representatives of our church, accepting that famous principle of unconditional obedience to the conqueror, created a bureaucratic organization from our church (...) Many of our church representatives with their titles and ranks with their work and way of life were truly church bureaucracy in the full meaning of the word." However, as the talks between the state and the church progressed, it was clear that the Episcopate would win and that the wish of a lower clergy and secularist from Bosnia and Herzegovina would not be respected for the creation of the National Church Council and its powers. Madžar, Papić 2005: 171-173.

12 Gligorije Jeftanović (Sarajevo 7 February 1840 - Sarajevo 15 March 1927) was a trader, landowner, national leader and politician. After the fall of the Ottoman Empire in the provinces of Bosnia and Herzegovina in July 1878, he was elected to the People's Government. He was the President and Vice-President of the Serbian ChurchSchool Municipality in Sarajevo. During the period of the fight of Serbs in the provinces of Bosnia and Herzegovina for church-school self-government he was one of the leaders of the movement. In 1910 he entered as a vital member of the Bosnian Parliament, where he was a member of the Finance, Budget and Oversight Committee. After the People's Council was formed in Bosnia and Herzegovina in October 1918, he was elected Chairman of the Main Board. Later on behalf of the People's Council of BiH he was delegated to the Plenum of the People's Council of Slovenians, Croats and Serbs in Zagreb, and after the war he was elected to the Provisional People's Presidency of the Kingdom of SHS. As the oldest deputy in 1919, he was the first interim Chairman of the Assembly. Urić 2009: 399-401; Kobasica 1927; Madžar 1982: 133, 171; Kruševac 1960: 290, 391.

13 From 1905 to 1914, Gligorije Jeftanović was the Deputy Chairman of this body, when the Austro-Hungarian occupation authority passed a decision on his removal. Kobasica 1927. 
Constantinople Patriarchate and the merge with the Serbian Patriarchate. Also, on 1 May 1919, Jeftanović attended the Conference of the members of the Eparchial Administrative and Educational Council in Sarajevo. ${ }^{14}$

The request to the Great Administrative and Educational Council in Bosnia and Herzegovina about the position of its members on the declaration for negotiations with the Constantinople Patriarchate arrived in July 1919 from Belgrade. After receiving the request, the Chairman of the Great Administrative and Educational Council Metropolitan of Dabar and Bosnia Evgenije (Letica) sent a request to the members of the Great Administrative and Educational Council to give their consent as soon as possible in order to send the answer to Belgrade. As Gligorije Jeftanović was a member of the Great Administrative and Educational Council, the Metropolitan Evgenije sent a letter to him on 19 July 1919, to declare in written on the mentioned issue:

(...) To Mister Gligorije Jeftanović (...) This Council has been informed from Belgrade that the delegation for the negotiation with the Constantinople Patriarchate for the secession of the Serbian Orthodox Church in Bosnia and Herzegovina from Constantinople and the merge of the same Church with Serbia requires the consent of this Council as a representative of the People and the Clergy.

For this reason, you are kindly asked as a member of this Council to give your consent for it by signing the enclosed document, because the matter is very urgent so we cannot wait for the regular convening of the Council session (....). ${ }^{15}$

Gligorije Jeftanović sent a reply to the Great Administrative and Educational Council on 22 July 1919, in which he gave his written consent:
(...) I am referring to the letter of that Council, number 317 from 1919, dated 19 July 1919, I send my written consent, as a member of the Council, that the Council can give official approval, that the Serbian Orthodox Church in Bosnia and Herzegovina can be separated from the matrix of the Eastern Orthodox Church in Constantinople and to merge with the Serbian Orthodox Church of the Metropolitanate of Belgrade (...). ${ }^{16}$

The lack of Jeftanović's personal signature is noticed on the document as well as the text that was handwritten under the signing place, saying: "I did not want to sign because I was deprived of that honor by the verdict of the Supreme Court and I have not been reactivated by the new Government." 17

Gligorije Jeftanovic in this answer was referring to the First World War trial that was led by the occupation authorities against him, which ended with an acquittal. ${ }^{18}$ The process

\footnotetext{
Historical Archive Sarajevo, Jeftanović Family Fund, box No. 10, No. 336 ex 1919. (HAS, FPJ)

HAS, FPJ, box no. 10, OJ-3001.

HAS, FPJ, box no. 10, OJ-3002.

Ibid.

18 Before the beginning of the trial in 1917, occupation Austro-Hungarian authorities held Jeftanović in house detention, to which he was sentenced immediately after the outbreak of the First World War in 1914. After the assassination of the crown prince and after the anti-Serbian demonstrations, a search of Jeftanović's immovable property was conducted in Sarajevo, during which they found in his stable the oval board with a large number of monograms and 15 coats of arms arranged in a way so that the state coat of arms of the Kingdom of Serbia was at the top and under the coats of arms of the countries belonging to the Monarchy (Dalmatia, Slavonia, Herzegovina, Bosnia, Croatia and Srem), which the occupying authorities saw as a
} 
began on 5 June 1917 by the occupation Austro-Hungarian authorities, who had been conducting an investigation against him since 1915 for the crime of treason because, as the occupation authorities considered, from 1899 until the outbreak of the First World War in 1914 he was associated with various politicians, diplomats and clerks of the Kingdom of Serbia with the aim of merging the occupied provinces of Bosnia and Herzegovina with the Kingdom of Serbia. ${ }^{19}$ In the trial, which lasted until 21 December 1917, a particular connection with Emil Gavril as a mercenary of the Serbian Government was emphasized. ${ }^{20}$ During this process, Stefan Burijan considered that there was no evidence that Gligorije Jeftanović worked on the separation of occupied provinces and their joining with Serbia and in his favour he also mentioned the report of the Serbian Consul from Budapest on 17 March 1909, which states: "Jeftanović stated that together with the entire Serbian people he opposes the annexation and demands full self-government with the guarantee of great powers, and that the word 'self-government' did not imply a complete separation from the framework of the Monarchy." According to his opinion, there was no basis for the occupying government to carry out the trial against Jeftanović. ${ }^{21}$

Jeftanović again addressed in writing the Great Administrative and Educational Council on 25 July and complicated the matter regarding the requested consent by saying that, as not being a member of the Great Administrative and Educational Council, he could not give his consent to the secession of the Orthodox Church in Bosnia and Herzegovina from the Constantinople Patriarchate and merging with the Serbian Orthodox Church:

To the Presidency of the Great Administrative and Educational Council in Sarajevo

To your much appreciated letter of 19 July no. 317 from 1919 I am honoured to answer the following: When a political criminal investigation was conducted against me in 1915, then - as I have learned so far - by the wish and at the request of the Black-and-Yellow Government and the agreement of the Chairman of the Great Administrative and Educational Council, the Office of the aforementioned Council was moved to Tuzla to make it easier for the former Government with evil intentions to put me to jail and this happened in the same 1915 when I was sentenced by the Criminal and Supreme Court and deprived of all civil rights and then I also lost the right to be the Deputy Chairman of that Council.

Neither the Presidency of the aforementioned Council nor the National Government to this day did not do their duty to reinstate/reactivate me to the previous title in writing as I deserved without any questions, therefore I do not considered myself a member of that Council and for that reason I cannot give any kind of consent to the secession of the Orthodox Church in $\mathrm{BiH}$ from the Matrix of the Eastern Orthodox Church in Constantinople and the merging with the Serbian Orthodox Church of the Belgrade Metropolitanate because I am not a member of the Great Administrative and Educational Council. ${ }^{22}$

On the same day, 25 July 1919, when Jeftanović sent the second letter, Metropolitan

Greater Serbian propaganda. Urić 2009: 400-401; Kruševac 1960: 386; Kobasica 1927; Mikić 2011: 285; Mikić 1996: 60-61, 64; Ekmečić 1996: 8-9.

19 Gligorije Jeftanović was among the signatories of the Serbian Resolution of the members of the BosnianHerzegovinian Parliament in support of the Serbian army in the Balkan War of 1912 and he was the Chairman of the Board for collecting aid to the Serbian army in the same war. Dujmović 2015: 177-178.

Mikić 1996: 63-64.

HAS, FPJ, box no. 10, OJ-3003. 
Evgenije responded positively to his remark and reinstated him to the position of Deputy Chairman of the Great Administrative and Educational Council. ${ }^{23}$ With this decision, Metropolitan Evgenije legalized Jeftanović's answer to the acceptance of the secession of the Orthodox Church in Bosnia and Herzegovina from the Constantinople Patriarchate and the merging with the Serbian Patriarchate.

On 30 September 1919, after the session of the Great Administrative and Educational Council in Sarajevo, Gligorije Jeftanović received a written decision on the reinstatement to the position of Deputy Chairman of the Great Administrative and Educational Council. On 23 August 1919 Jeftanović received an invitation to attend the session of the Great Administrative and Educational Council which would be held on 30 September in Sarajevo $^{24}$ and, as accompanying material, the Agenda composed of 11 items. $^{25}$

At the end of the session on 30 September 1919 the new Chairman of the Great Administrative and Educational Council, the Metropolitan of Banja Luka and Bihać Vasilije (Popović), who was elected at that session instead of the ill Metropolitan of Dabar and Bosnia Evgenije (Letica), responded in writing to Gligorije Jeftanović about his reinstatement to the position of Deputy Chairman of the Great Administrative and Educational Council:

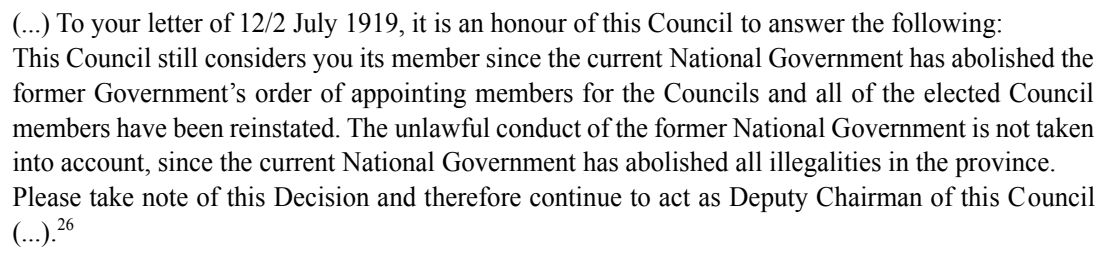

However, despite the decision of the Great Administrative and Educational Council to accept Gligorije Jeftanović's complaint and make the Decision to inform him in writing about the reinstating to the position of Deputy Chairman, Jeftanović refused to be reinstated as a member and to the position of Deputy Chairman.

The correspondence between Gligorije Jeftanović and the Eparchial Administrative and Educational Council followed in the period November-December 1919. First, the Eparchial Administrative and Educational Council in Sarajevo sent an invitation to Jeftanović on 10 November 1919 to attend the session of the Council on 29 November $^{27}$ and Jeftanović sent a reply on 20 November 1919 in which he referred to the content of his letter dated 25 July 1919, in which he explicitly stated that he no longer considered himself a member of the Great Administrative and Educational Council and the Eparchial Administrative and Educational Council:

(...) In reply to your appreciated letter of 28/X - 10/X no. 324 ex 1919 I am honoured to announce the following:

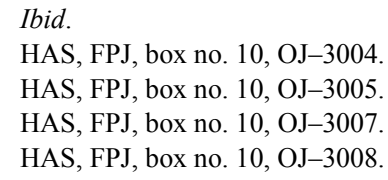


As I already answered in my letter on 12/25 July 1919 to the Great Administrative and Educational Council, I repeat it today as well and stand in the firm belief that everything is the same as I indicated in the abovementioned letter, and I no longer consider myself the Deputy Chairman of the Great Administrative and Educational Council as well as a member of the Eparchial Administrative and Educational Council (...). ${ }^{28}$

To this Jeftanović's letter, at its session on 29 November 1919, the Eparchial Administrative and Educational Council made a Decision that continued to consider Jeftanović its member, stating in the Decision that the Eparchial Administrative and Educational Council was not familiar with his letter to the Great Administrative and Educational Council of 25 July 1919:

(...) Gligorije Jeftanović in Sarajevo with his submission dated 7/20 November this year, referring to his letter dated 12/25 July this year, sent to the Great Council, where, as he says, remains, reports to this Council, that he no longer considers himself a member of this Council.

Resolution:

Gligorije Jeftanović is to be informed that this Council is now aware of the content of his letter dated 12/25 July this year, sent to the Great Council, but still considers him a member of this Council, since he is not excluded from it and his presence at the conference of members of this Council from Sarajevo held on 18 April - 1 May 1919 proves that he still considered himself a member of this Council (....). ${ }^{29}$

Even after receiving this Decision on 24 December 1919, Jeftanović remained consistent with his position that he was no longer a member of the Eparchial Administrative and Educational Council, which, in a letter dated 25 December 1919 he explained to the Eparchial Administrative and Educational Council, stressing that his return to the post of Deputy Chairman of the Great Administrative and Educational Council can only be solved by the National Government, because the Government, only in the former state, removed him from this position with the assistance of a certain circle of people precisely from the Great Administrative and Educational Council: ${ }^{30}$

(...) Referring to your letter of $16 / 2$ November this year no. 336, from 1919; I'm sending you a copy of my letter from 12/2 July this year addressed to the Great Council and I would like to ask you to take my statement, which is contained in the above copy of the letter - for your reference and for your future actions, because in your above-mentioned letter i.e. Decision, you claim that the contents of my said letter are unknown to you.

In addition, in your previously mentioned Decision you mention the Council meeting of 18 April

- 1 May 1919 and you claim that I was present at this session, therefore this is the truth that cannot

HAS, FPJ, box no. 10, OJ-3010.

HAS, FPJ, box no. 10, No. 336 ex 1919.

30 Members of the Great Administrative and Educational Council in 1914 were: Metropolitan of Zvornik-Tuzla Ilarion (Radonić) (Chairman), Metropolitan of Dabar and Bosnia Evgenije (Letica), Metropolitan of Zahumlje and Herzegovina Petar (Zimonjić) and Metropolitan of Banja Luka and Bihać Vasilije (Popović); Laymen: Gligorije Jeftanović (Deputy Chairman), Risto Damjanović, Milan Srškić, Sava Vukanović, Milan Šušljić, Pero Stokanović, Isailo Mičić, Stevo Žakula, Vojo Panić, Stevo Nikolić, Živko Nježić, Vaso Glušac, Nikola Cikota, Janko Misaljević, Svetislav Bugarski, Atanasije Šola, Dušan Vasiljević, Jovo Tuta, Jovo Dučić and Pavle Čonić; Priests: Kosta Prodanović, Dušan Kecmanović, Kosta Dramušić and Vasilije Kondić. Kalendar Bošnjak 1914: 155. 
be denied. But the truth is also that on that day there was no formal session, which should be convened and held according to the regulations, but it was an informal meeting without a certain formality, which could be called the "Casual Meeting", and to which only a few people came and they were only those people who get along well and have a friendly relationship in their private life, so I then came there in that capacity to my friends and with that intention, to see them and ask how they are and talk about private things. But even if it was not an official invitation, as I said before, at the same time one official question was raised which was then discussed and this question was related to some of the allowances for priests and I was of course there, but my gathered colleagues at that meeting did not need to consider me a member of the Eparchial Administrative and Educational Council even more because the Black-and-Yellow Government resolved me the position of the Deputy Chairman of the Great Administrative and Educational Council with the assistance of our Church head and our Government does not know anything about it today and I wonder where are our champions are, who were working by the wish and the orders of the Black-and-Yellow Government, which it resolved me of the previously mentioned duty.

Now again some of our Serbian gentlemen from the Great i.e. Eparchial Administrative and Educational Council think that they can do things using me and appoint me as some member and when it suits them invite me to sessions. This act from them for me is not worth a damn. For me, only the Government's appointment is relevant, since it removed me from this position and then it is not possible that the lower body appoint me over the higher. But as our proverb says, that the grapes are sour for the fox, so she cannot bite it with her teeth, it is the same for the gentlemen who were indifferent during the former Government when I was sent to prison to step out to the current real Government with their previous document and to appoint me again, which I do not even want but only this I say, because I know foxes are hiding from that.

For now, I say this $(\ldots)^{31}$

After this Jeftanović's letter the Eparchial Administrative and Educational Council remained without an answer until the end of 1919. And it is evident that Jeftanović did not want to return to this body because he thought that actually people who, even after the First World War, were sitting in that body were the people sitting there before the war, but also during the war, and who bear the guilt for his removal from the position of the Deputy Chairman and member of this body and court process during the war itself.

The first following invitation was sent by the Eparchial Administrative and Educational Council to Gligorije Jeftanović on 15/28 April 1920 and is related to the sale of land in Kolodvorska Street across the Museums, the construction of shops in Kralja Petra Street and presidial issues in Sarajevo. ${ }^{32}$ But the answer is not saved, if Jeftanović even sent it at all. ${ }^{33}$

\section{REFERENCES:}

Archive material:

Historical Archive of Sarajevo:

Jeftanović family fund.

31 HAS, FPJ, box no. 10, Letter of Gligorije Jeftanović to the Eparchial Administrative and Educational Council dated 12/1 December 1919.

32 HAS, FPJ, box no. 10, OJ-3010.

33 The administrative and judicial bodies of the Serbian provincial churches were abolished on 13 December 1920, by passing the Provisional Regulation on Centralization of Administrative and Judicial Powers in the Serbian Patriarchate. 
Published sources:

Definitivni rezultati popisa stanovništva od 31. januara 1921. godine, Sarajevo: Državna štamparija, 1932.

Rezultati popisa žiteljstva u Bosni i Hercegovini od 10. oktobra 1910. godine, Sarajevo: Zemaljska vlada za Bosnu i Hercegovinu, 1912.

Šematizam svijeh oblasti u Bosni i Hercegovini, Kalendar Bošnjak za 1914, Sarajevo, 1914.

Periodicals:

Dimović, D. 'Iz mojih uspomena', Pravda, 12.360, 8-11. april 1939. (Serbian Cyrillic)

Istočnik, 8-9, 30. septembar 1905. (Serbian Cyrillic)

Kobasica, S. 'Gligorije Jeftanović', Politika, 6.785, 16. mart 1927. (Serbian Cyrillic)

References:

Branković, B. 'Od polubogova do nacionalnih izdajnika i optuženika za veleizdaju', u: Đ. Čekrlija (ur.), Autoritarna ličnost i društvo, knj. 3, Ličnost i društvo, Banja Luka: Filozofski fakultet u Banjoj Luci, 2017, 27-34. (Serbian Cyrillic)

Davidović, S. Srpska pravoslavna crkva u Bosni i Hercegovini (od 960. do 1930. god.), Sarajevo: Srpska pravoslavna crkvena opština Sarajevska, List „Dabar“, 1991. (Serbian Cyrillic)

Dujmović, S. Sarajevska srpska čaršija 1918-1941. - između tradicije i modernizacije, Beograd: Filozofski fakultet, 2015.

Ekmečić, M. ‘Žalosna baština iz godine 1914.’, u: N. B. Popović (ur.), Politički procesi Srbima u Bosni i Hercegovini 1914-1917, Laktaši: Grafomark, 1996, 7-47. (Serbian Cyrillic)

Gligorijević, B. 'Ujedinjenje Srpske pravoslavne crkve i uspostavljanje Srpske patrijaršije u Jugoslaviji', Istorija 20. veka, XV-2, 1997, 7-18.

Kruševac, T. Sarajevo pod austro-ugarskom upravom 1878-1918, Sarajevo: Muzej grada Sarajeva, 1960. (Serbian Cyrillic)

Madžar, B. Pokret Srba Bosne i Hercegovine za vjersko-prosvjetnu samoupravu, Sarajevo: Veselin Masleša, 1982. (Serbian Cyrillic)

Madžar, B., Papić, M. Politika i Srpska pravoslavna crkva u Bosni i Hercegovini 1878-1945, Banjaluka: SPKD Prosvjeta, GO Banjaluka, 2005. (Serbian Cyrillic)

Mikić, Đ. 'Veleizdajnički procesi u austrougarskoj politici u Bosni i Hercegovini', u: N. B. Popović (ur.), Politički procesi Srbima u Bosni i Hercegovini 1914-1917, Laktaši: Grafomark, 1996, 4992. (Serbian Cyrillic)

Mikić, Đ. Austrougarska ratna politika u Bosni i Hercegovini 1914-1918, Banjaluka: NUBL, 2011.

Milošević, B. Srpska pravoslavna crkva i sveštenstvo u Bosni i Hercegovini u Prvom svjetskom ratu, Višegrad: Andrićev institut, 2016. (Serbian Cyrillic)

Milošević, B. 'Uredba crkveno-prosvjetne uprave srpskih pravoslavnih eparhija (mitropolija) u Bosni i Hercegovini', u: B.M. Branković i B. Milošević (ur.), Stotinu dvadeset godina od početka borbe srpskog naroda u Bosni i Hercegovini za crkveno-školsku samoupravu (1896-1905), Zbornik radova, Banja Luka: Filozofski fakultet u Banjoj Luci, 2017, 71-88. (Serbian Cyrillic)

Novaković, D. Verske zajednice na razmeđu vekova, Beograd: Institut za političke studije, 2003. (Serbian Cyrillic)

Novaković, D. 'Donošenje prvog Ustava Srpske pravoslavne crkve 1931. godine', Zbornik Matice srpske za društvene nauke, 146, 2014, 41-54. (Serbian Cyrillic)

Luković, K. 'Srpska pravoslavna crkva', u: Jubilarni zbornik života i rada Srba, Hrvata i Slovenaca, deo 2, Beograd: Matica živih i mrtvih SHS, 1929, 622-632. (Serbian Cyrillic)

Ljubibratić, S. 'Organizacija i samoupravno uređenje Srpske pravoslavne crkve', Kalendar Prosvjeta, 1928, 42-48. (Serbian Cyrillic) 
Slijepčević, Đ. Istorija Srpske pravoslavne crkve, knj. 2, Beograd: JRJ, 2002. (Serbian Cyrillic)

Urić, N. 'Jeftanović, Gligorije M.', u: Srpski biografski rečnik, tom 4, Novi Sad: Matica srpska, 2009, 399-401. (Serbian Cyrillic)

БОШКО М. БРАНКОВИТ

Универзитет у Бањалуци, Филозофски факултет

Одсек за историју

\title{
ПРЕПИСКА ГЛИГОРИЈА ЈЕФТАНОВИТА И ВЕЛИКОГ УПРАВНОГ И ПРОСВЈЕТНОГ САВЈЕТА 1919. ГОДИНЕ
}

\begin{abstract}
Резиме
Завршетак Првог свјетског рата донио је ослобођење и уједињење свих српских покрајина, те је тако створена могућност да се изврши уједињење обласних српских цркава у самосталну Српску православну цркву. Припреме око проглашења уједињења српских обласних цркава у једну трајале су од 31. децембра 1918. године до 26. маја 1919. године, када је збор свих српских православних епископа одлучио да изврши уједињење. У току преговора са Цариградском Патријаршијом 1919. године у Босни и Херцеговини, која је црквено била под јурисдикцијом ове Патријаршије, значајну улогу за канонско отцјепљење од Цариградске Патријаршије и припајање Српској Патријаршији имао је Велики управни и просвјетни савјет у коме су, по Уредби о уређењу самоуправних ирквено-просвјетних прилика из 1905. године, поред црквених, сједила и свјетовна лица, а једно од њих је био и Глигорије Јефтановић, те је било потребно прибавити и његово мишљење. Глигорије Јефтановић је дао своју писмену сагласност, али уз напомену да он није члан Великог управног и просвјетног савјета, што је довело до преписке Великог управног и просвјетног савјета и њега до краја 1919. године, у којем је Митрополит, као предсједник Великог управног и просвјетног савјета, тврдио да је он (Глигорије Јефтановић) члан и потпредсједник Великог управног и просвјетног савјета, а Глигорије Јефтановић је тврдио да није члан, јер му та част није враћена одлуком нове Владе, а одузета му је одлуком старе, окупационе аустроугарске Владе 1914. године. У последњем писму, које је Глигорије Јегтановић упутио Епархијском управном и просвјетном савјету, из сачуване преписке, од 12/25. децембра 1919. године види се да је Глигорије Јефтановић остао при свом ставу, да није члан Великог управног и просвјетног савјета и Епархијског управног и просвјетног савјета. На основу преписке и историјских чињеница данас познатих, немамо разлога да сматрамо или закључимо да је он промијенио мишљење, јер су управни и судски органи српских покрајинских цркава укинути 13. децембра 1920. године доношењем Привремене уредбе о централизаиији управне и судске власти у Српској Патријаршији, а из доступних архивских докумената видљиво је, да је Епархијски управни и просвјетни савјет, Глигоријуе Јефтановићу послао још само један позив од 15/28. априла 1920. године, на који Јефтановић није одговорио.
\end{abstract}

Кључне ријечи: Глигорије Јефтановић, Српска православна црква, Краљевина Срба, Хрвата и Словенаца (Краљевина СХС), Босна и Херцеговина, Велики управни и просвјетни савјет. 